\title{
Ordenamento territorial e urbano da ilha da Madeira: relevância do Funchal neste processo
}

\section{José Roberto Ribeiro Rodrigues}

rrodrigues.arquitecto@gmail.com

RR Arquitecto - Arquitectura+Planeamento | Assembleia Legislativa da Madeira | Comissão Especializada de Ambiente e Recursos Naturais

Para citação: RODRIGUES, José Roberto - Ordenamento territorial e urbano da llha da Madeira: relevância do Funchal neste processo. Estudo Prévio 14. Lisboa: CEACT/UAL - Centro de Estudos de Arquitetura, Cidade e Território da Universidade Autónoma de Lisboa, 2018. ISSN: 2182-4339 [Disponível em: www.estudoprevio.net]. DOI: https://doi.org/10.26619/2182-4339/14.2

Artigo recebido a 20 de setembro de 2018 e aceite para publicação a 20 de dezembro de 2018. Creative Commons, licença CC BY-4.0: https://creativecommons.org/licenses/by/4.0/

\section{Resumo}

O artigo aborda as transformações territoriais decorrentes de tentativas de ordenamento e da consequente urbanização do território da ilha da Madeira verificadas desde o povoamento do arquipélago, apresentando elementos cartográficos que exemplificam esses importantes momentos da sua história.

Tal permite perceber as transformações urbanas ocorridas, e os consequentes efeitos no território insular, tendo como ponto de partida o Funchal, a sua primeira urbe, centro nevrálgico e local onde as transformações do território foram mais significativas e determinantes.

A par disto é feita uma abordagem ao sistema regional de gestão territorial e a sua aplicação na região, tendo em conta a gestão do território nas últimas décadas.

E por fim é feita uma análise crítica de todos estes processos, apontando fragilidades como caminhos a seguir no sentido de melhorar ou colmatar falhas detetadas que importa resolver no futuro próximo.

Palavras-Chave: Território, Funchal, Planos, Programas, Ocupação, Região Autónoma. 


\section{0 arquipélago da Madeira}

O arquipélago da Madeira, insere-se no Atlântico Norte, explorado desde o século VII a.C. e, embora de uma forma não sistemática, já era conhecido dos exploradores que navegavam o Atlântico (Carita, 2017).

O povoamento do arquipélago surgiu, neste quadro, como o primeiro passo de uma atividade nova. Primeira experiência de povoamento e de exploração das terras, para a llha vieram os pioneiros de uma mentalidade universalista, que aqui deram assento a uma nova sociedade (Carita, 2017).

O arquipélago é composto por duas ilhas principais - Madeira e Porto Santo - e por dois grupos de ilhas desabitadas: as Desertas, protegidas desde 1990, constituem uma reserva natural e as Selvagens, candidatas a Património Mundial da UNESCO (ACAPORAMA, 2016).

Com $758 \mathrm{~km} 2$, a ilha da Madeira concentra uma enorme diversidade de paisagens, de vegetação, de microclimas e de tradições. (adaptado de ACAPORAMA, 2016). Estas paisagens representam um importante contributo para o turismo a sua principal atividade económica na atualidade.

$\mathrm{O}$ arquipélago tem uma superfície de $801 \mathrm{~km} 2$ e 267.785 habitantes. Com base nas estimativas populacionais de 2013, da Direção Regional de Estatística da Madeira (DREM), a densidade populacional é de 327 habitantes por km2 (ACAPORAMA, 2016). O relevo do arquipélago é diversificado. A Ilha da Madeira tem uma topografia muito acidentada e o ponto mais alto é o Pico Ruivo (1.861 m de altitude). A llha de Porto Santo tem uma topografia muito plana, com uma tira de areia dourada de $9 \mathrm{~km}$. As Ilhas Desertas têm um relevo escarpado, ao contrário das llhas Selvagens (adaptado de ACAPORAMA, 2016). 


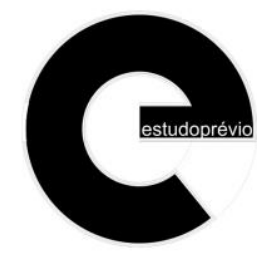

PT | P01 | EP14 | w2018



Figura 1 - "Descrição da ilha da Madeira, Cidade do Funchal, Villas, Lugares, Ribeiras, Portos e Enseadas, e mais Secretos, feita por Pertolomeu loão Inginro Della em tempo Governador Bertolomev de Uasconcelos da Cunha, Capitão Geral desta Ilha no ano de 1654". Rui Carita - Arquitetura Militar na Madeira, Séculos XVI a XIX. Fundação Calouste Gulbenkian. Lisboa. 1982.

A costa sul, muito mais abrigada e soalheira, cedo se revelou muito mais produtiva que a costa norte. Servida por uma ampla baía abrigada, o inicial lugar do Funchal prosperou rapidamente, impondo-se a toda a ilha. O Funchal, revelou-se o local ideal para a instalação dos primeiros povoadores, à semelhança das urbes continentais, sempre dotadas de uma parte baixa, residência das classes trabalhadoras e de uma alta, para residência dos quadros dirigentes (adaptado de Carita, 2017).

O Arquipélago da Madeira é, desde 1976, uma região autónoma da República Portuguesa, com um Parlamento e Governo próprios. A sede do Governo Regional está situada no Funchal. A região está subdividida em onze municípios: Funchal, Câmara de Lobos, Ribeira Brava, Ponta do Sol, Calheta, Porto Moniz, São Vicente, Santana, Machico, Santa Cruz e Porto Santo (adaptado de ACAPORAMA, 2016).

\section{A herança histórica: O crescimento urbano da Ilha a partir do Funchal:}

Após o início do povoamento da Madeira, por volta de 1425 e por determinação de D. João, ocorre a formação de um primitivo povoado na zona leste da baía do Funchal, batizado de Santa Maria ou Santa Maria do Calhau (Aragão, 1992). Aquela que se pode considerar a primeira organização 
urbana da llha, surge com a primária ou elementar orgânica urbana do primitivo povoado funchalense. Esta se organizava junto à pequena igreja de Santa Maria, estendia-se num chão que deslizava até ao calhau e servia de espaço social, de convívio e comércio. À ilharga levantava-se um improvisado cemitério, junto abria-se o indispensável poço público e, a partir da lgreja, corria para nascente a primeira rua aberta na área do Funchal (adaptado de Aragão, 1992).

O povoado oferecia assim uma imagem humilde, convocado por edifícios térreos, na sua maioria construídos de madeira e cobertas de colmo. Por volta de 1452, o lugar do Funchal é elevado a categoria de concelho e um pouco mais tarde, em 1461, também os lugares de Câmara de Lobos, Ribeira Brava, Ponta do Sol e Arco já abrigavam um notório aumento de moradores. (adaptado de Aragão, 1992).

O Funchal registou um expressivo surto de construção entre os finais do século XV e inícios do século XVI e ao seu porto passaram afluir gentes e mercadorias de todo o mundo (Carita, 2017). $A$ vinda de mais povoadores levou à expansão deste primeiro núcleo populacional. Novas vias vieram enobrecer o traçado urbanístico da vila do Funchal. Casas de madeira e colmo, reflexo da cultura cerealífera e do imenso arvoredo à volta povoaram as novas travessas, azinhagas e becos, enriquecendo este primeiro aglomerado urbano, onde se fixaram os artesãos, enquanto outro núcleo populacional se formou onde vivia o futuro capitão donatário, nos arrifes de Santa Catarina (Vasconcelos, 2008).

O desbravamento subsequente e a fixação para um ponto mais no interior, subindo assim a encosta, determinou novos arruamentos, agora seguindo a linha das ribeiras e enriquecendo a estrutura viária do aglomerado. Estes três pontos de fixação humana foram fundamentais na estruturação urbanística da futura cidade do Funchal (adaptado de Vasconcelos, 2008).

O primitivo povoado de Santa Maria do Calhau, teve uma rápida expansão urbana no sentido esteoeste, e ao longo da orla marítima e conduziu à ocupação do espaço entre as três ribeiras. A riqueza açucareira proporcionou a densificação da rede viária dando lugar a novas ruas, como a de Santa Catarina e a dos Mercadores, possibilitando este arruamento a expansão para ocidente. Por volta de 1470, o duque D. Fernando determinou a cobertura em telha das casas da rua dos Mercadores e, em 1471, os limites da então vila do Funchal demarcaram-se por Santa Catarina, São Pedro, Santa Luzia, indo até a casa do capitão. (adaptado de Vasconcelos, 2008).

No período de riqueza açucareira construíram-se no Funchal grandes equipamentos. Com efeito, na última década do século XV e primeiros anos do século XVI, sob a orientação de D. Manuel, edificaram-se na cidade vários edifícios monumentais para a época, apetrechamento urbano deste núcleo populacional que pretendeu ensaiar uma dinâmica que depois se aplicou ao Reino, procedendo-se à reformulação do velho burgo de artesãos, na vila que foi elevada a cidade em 1508 (Adaptado de Vasconcelos, 2008). 


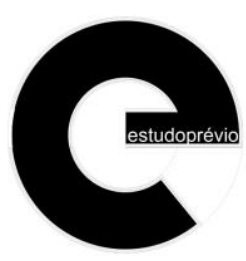

PT | P01 | EP14 | w2018

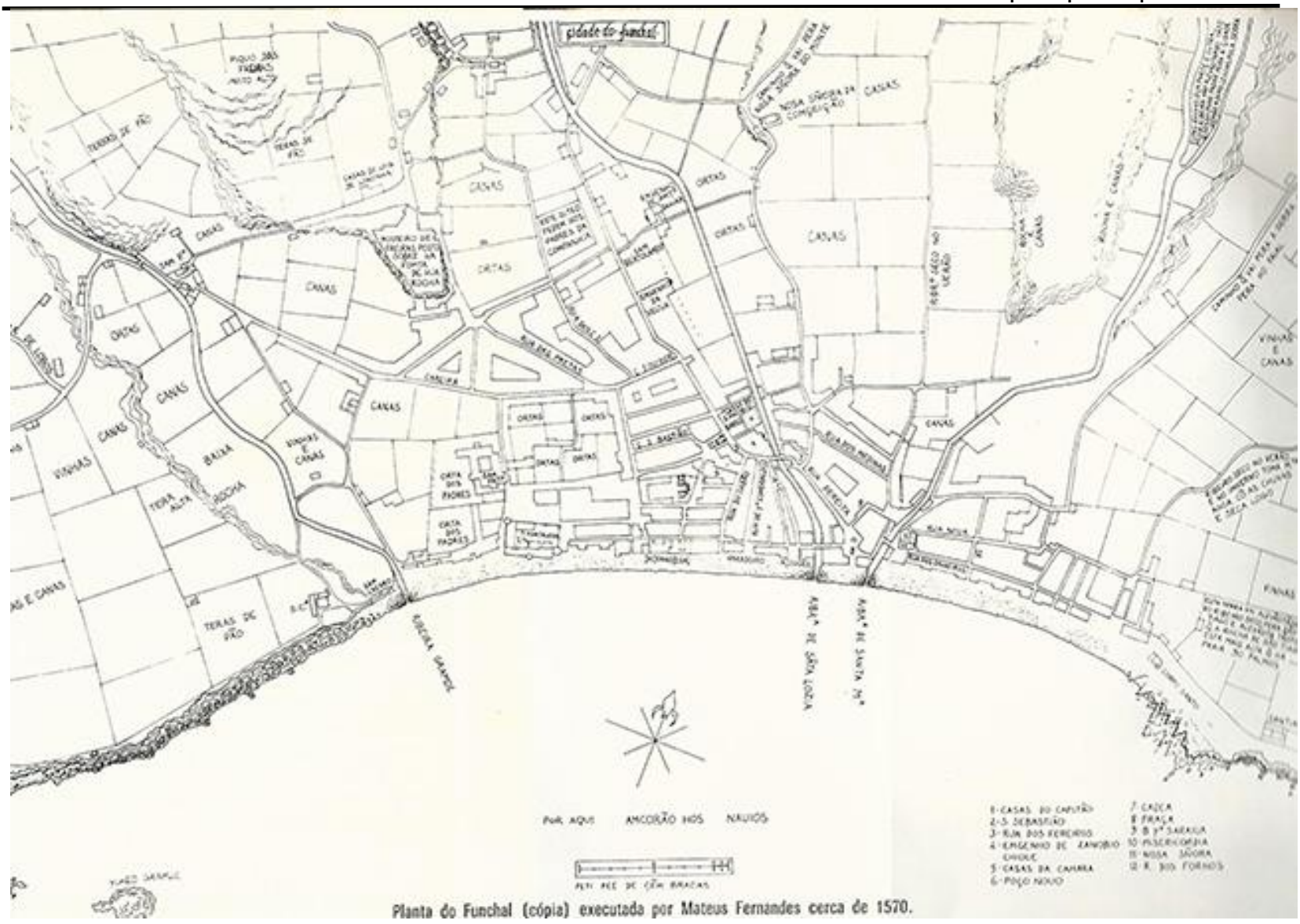

Figura 2 - "Planta do Funchal (cópia) executada por Mateus Fernandes cerca de 1570". António Aragão - O Espírito do Lugar, A Cidade do Funchal. A. Aragão. 1a Edição. Rio de Mouro. 1992.

\section{A organização urbana a partir da construção de fortificações:}

Depois de um ataque de um navio biscainho, em 1528, que roubara dois navios no porto do Funchal, foi pedida ao rei a construção de uma fortificação, queixando-se a população de que nada assegurava a defesa do porto (Carita, 2017). Em 1542 ter-se-á completado o plano inicial dum baluarte, uma torre e uma cortina de muralhas com dois portões, um virado à cidade e outro ao mar, conforme o determinado a João Cáceres (Carita, 1982).

Após o ataque dos corsários de 1566, no ano seguinte é enviado à ilha Mateus Fernandes fortificador e mestre das Obras Reais. A partir desta data, sucedem-se inúmeros documentos com determinações sobre a organização das fortificações. Um dos planos compreendia uma grande fortaleza, que situada no Alto da Pena, descia até ao bairro de Santa Maria, podendo nela abrigar toda a população da então cidade do Funchal (adaptado de Carita, 1982). 


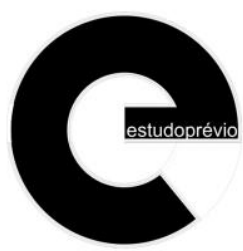

PT | P01 | EP14 | w2018

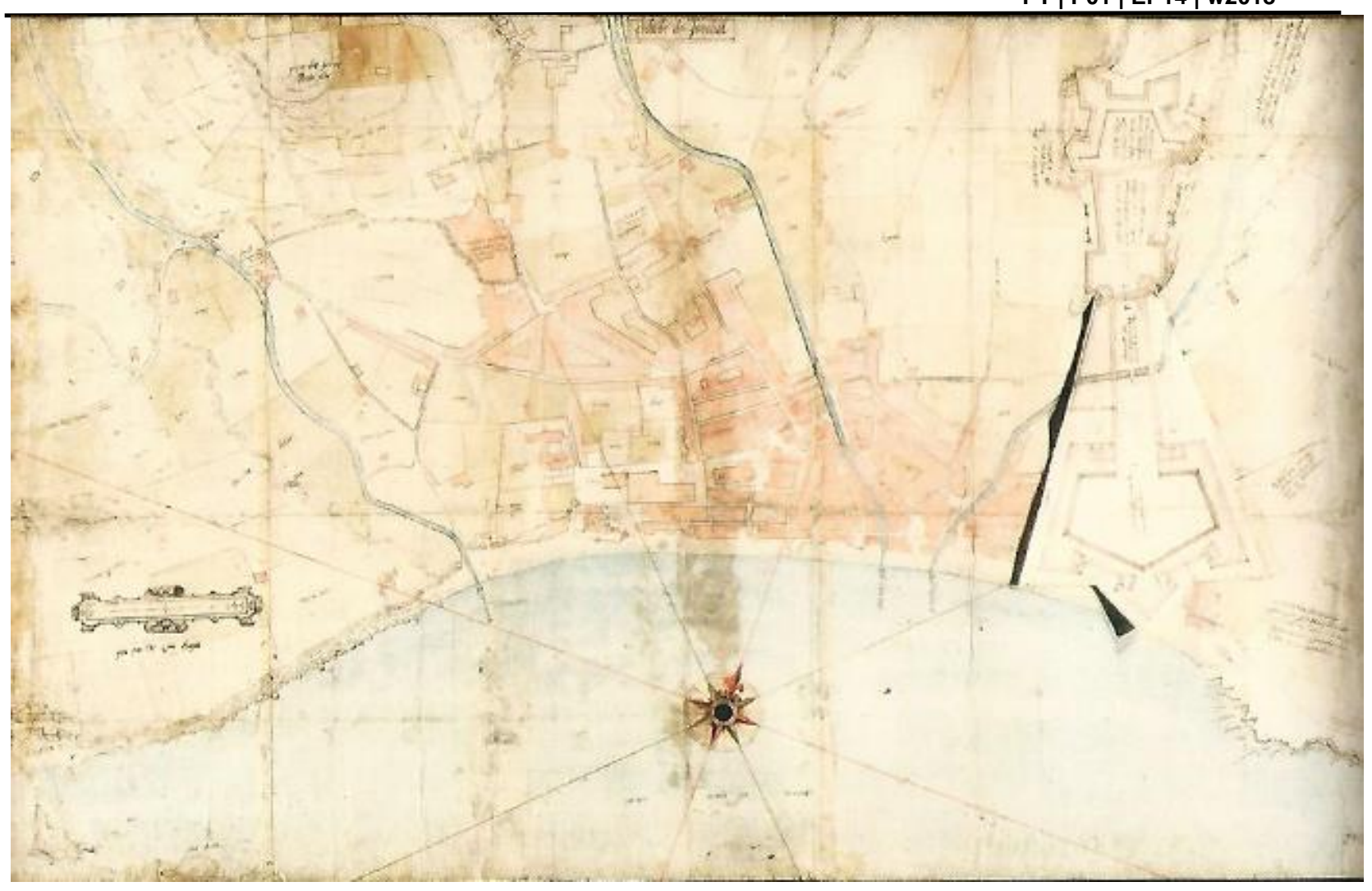

Figura 3 - "Planta da Cidade do Funchal 1567 a 1570, Mateus Fernandes". Rui Carita - História do Funchal. Associação Académica da Universidade da Madeira. Grafimares, Lda. 2ª Edição. Funchal. 2017.

Com o alvará sobre fortificação de 1572, a ordenação das muralhas destina-se ao Funchal, mas a mais lugares e pontos da ilha, podendo dizer-se que esta foi a primeira tentativa quer de proteção de outros núcleos populacionais para além do Funchal, quer de ordenamento pelos reflexos introduzidos por estas obras militares. No Funchal, a ordenação de muralhas foi prevista frente ao mar e entre as ribeiras de N. ${ }^{\text {a S. }}$ - do Calhau (atual ribeira de João Gomes) e a ribeira Grande (hoje de São João), acompanhando o curso dessas ribeiras e fechando nos picos da Pena e dos Frias (hoje de São João). Especifica ainda a construção da estância do Largo do Pelourinho, assim como os arranjos a fazer à fortaleza, essencialmente o arranjo de bateria baixa, virada hoje à Avenida do Mar e a construção de 3 baluartes, um virado também à Avenida do Mar e onde se desenvolve hoje o Palácio e os outros dois, dos extremos, virados à cidade. Depois de especificar o número de portas que deveria ter a muralha, o rei manda fortificar os demais portos da cidade do Funchal até Machico. Em 1614, a cidade do Funchal cresce para além dos limites do plano, o que obriga ao lançamento de um novo fecho de muralhas para leste, ponto do burgo que virá a ser chamado de São Tiago (adaptado de Carita, 1982).

Poucas mais informações há sobre a fortificação da ilha. Em 1632 existiam mais 9 fortificações, além das apontadas para o Funchal, surgindo fortificações em Câmara de Lobos, em Machico e na Calheta (adaptado de Carita, 1982). 

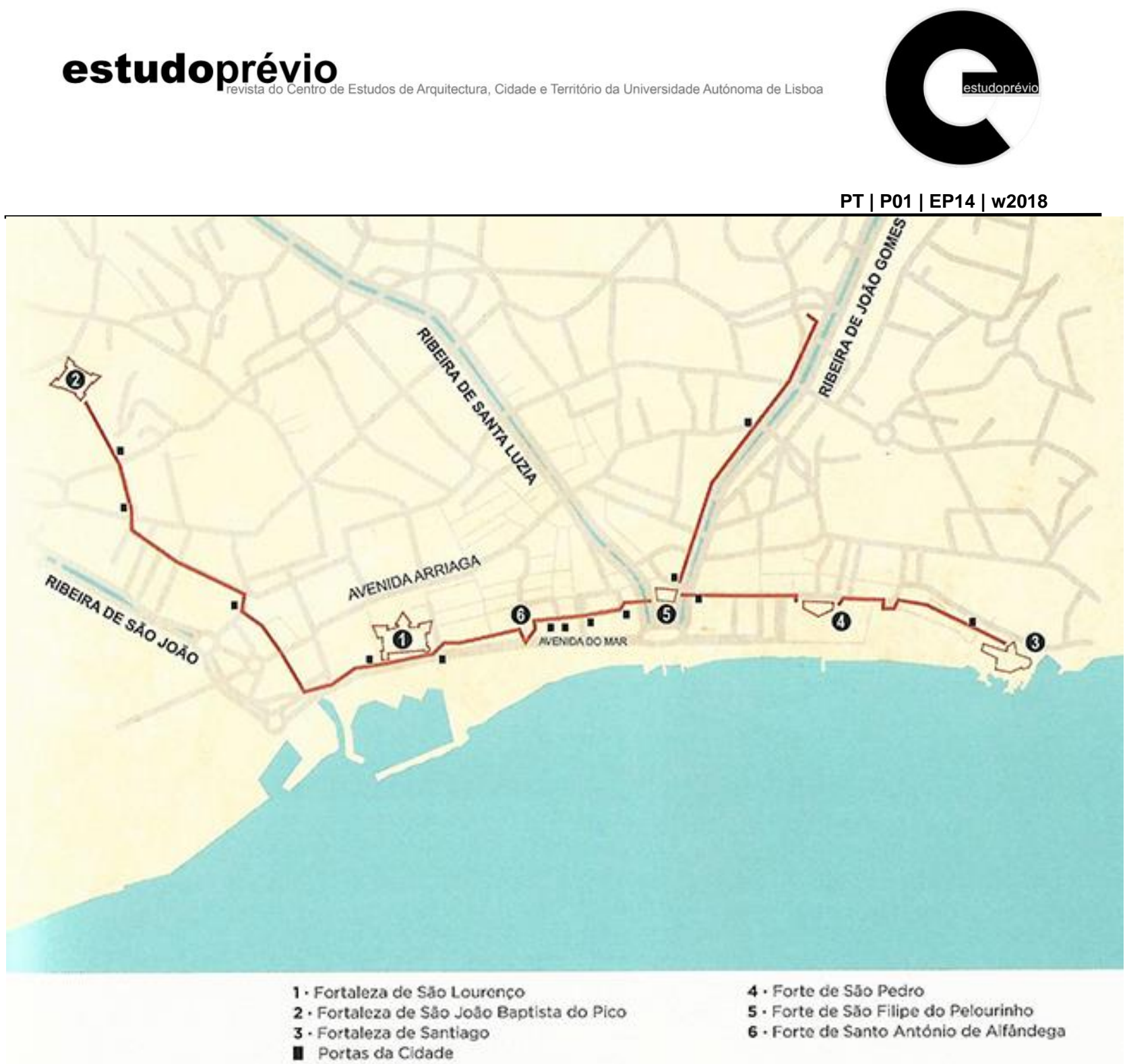

Figura 4 - "Reconstituição da muralha da cidade e das suas fortalezas no fim do século XVIII sobre uma planta atual da cidade do Funchal (2013). Está indicada a localização de 13 portas da cidade das 16 que existiram. Acervo António Aragão, ARM". Rui Carita - História do Funchal. Associação Académica da Universidade da Madeira. Grafimares, Lda. 2ª Edição. Funchal. 2017.

\section{Séculos XVII e XVIII: Remodelação da Malha Urbana do Funchal:}

A riqueza do vinho, particularmente relevante entre os séculos XVII e XVIII, proporcionou uma remodelação arquitetónica na malha urbana dos núcleos urbanos da Ilha, em particular da funchalense, onde surgem palácios, casas de habitação, escritórios e lojas de comércio. Os mercadores do Funchal transformaram as pequenas casas térreas em habitações sobradas, servidas por caves onde se guardavam as pipas, persistindo ainda exemplares da época. Edifícios com fachadas rendilhadas em cantaria negra com varandas de ferro forjado a servir inúmeras janelas, onde não falta a típica torre avista-navios (adaptado de Vasconcelos, 2008).

Este ciclo económico trouxe outra dinâmica aos arredores da cidade com o crescimento do número de quintas madeirenses, passando muitas, à posse de comerciantes ingleses no decurso do século XIX. Às quintas estão associados magníficos jardins e quase sempre, uma pequena construção a 
servir de mirante num canto do jardim, a "casa de prazeres", bem como uma capela para a vida religiosa da família e dos seus servidores (Vasconcelos, 2008).

O bem-estar trazido pela exportação do vinho terminou na primeira metade do século XIX, registando-se no segundo quartel daquela centúria uma drástica diminuição da exportação e o agravamento geral das condições de vida da ilha. Aos nossos dias chegaram, no entanto, bons exemplares da arquitetura da época e prenuncio de um novo tempo que assentará no turismo terapêutico, que utiliza as quintas para hospedar visitantes (adaptado de Vasconcelos, 2008).

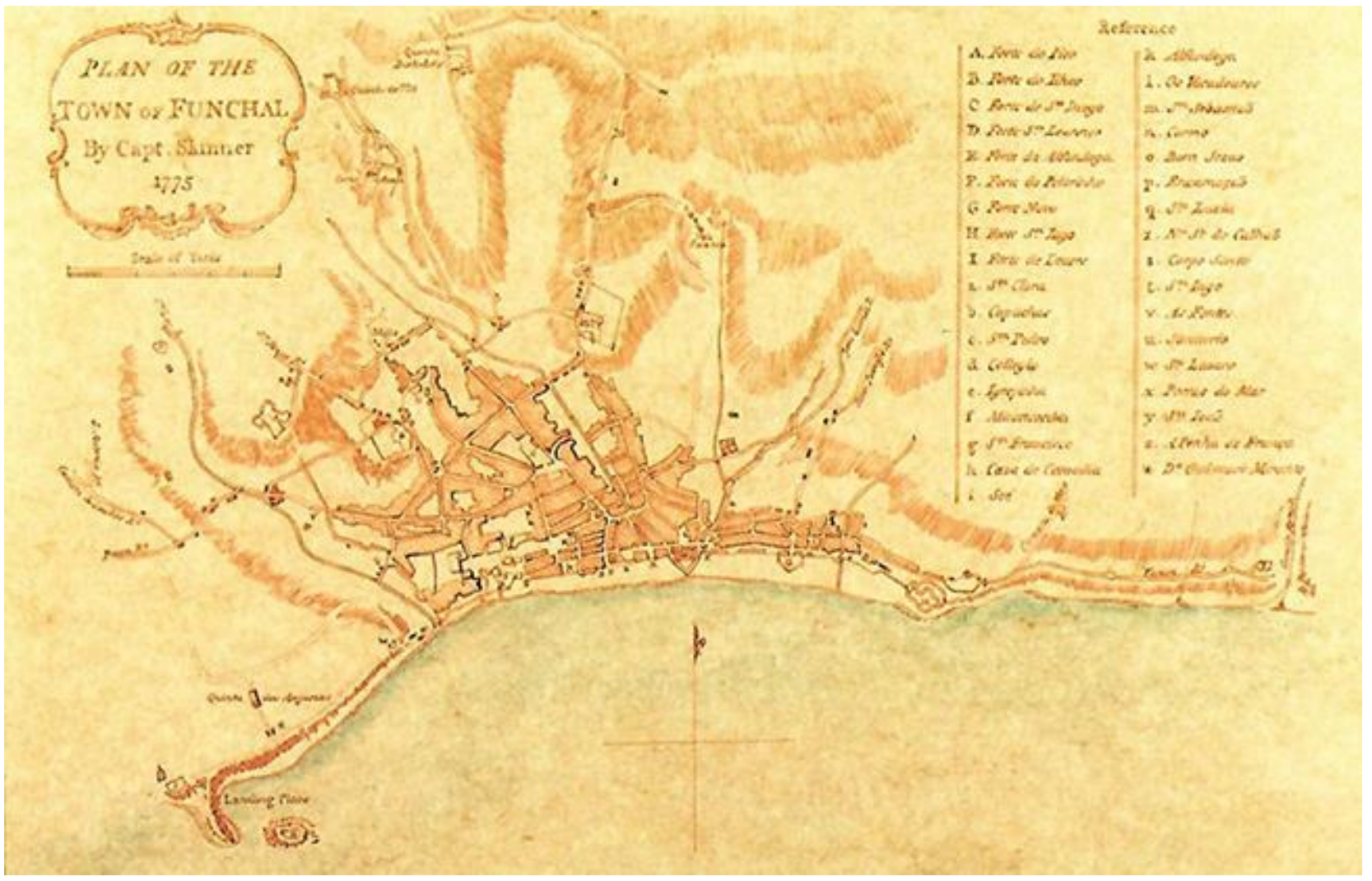

Figura 5 - "Mapa do Funchal do Cap. Skinner (1775), cópia de pormenor da Planta de Willian Johnston, ed. Londres, 1791. Acervo Rui Carita, ARM". Rui Carita - História do Funchal. Associação Académica da Universidade da Madeira. Grafimares, Lda. 2ª Edição. Funchal. 2017.

\section{As vulnerabilidades, os condicionalismos e as respostas dadas na gestão do território}

Em 1803, aconteceu uma aluvião que causou uma enorme catástrofe na llha, fenómeno cujas consequências estiveram ligadas diretamente com o estado de erosão das margens das ribeiras. Perante a catástrofe o governador reclamou a vinda à Madeira de um oficial de engenharia competente para dirigir os trabalhos de reparação de estragos causados (adaptado de Carita, 1982).

A aluvião permitiu encetar um pensamento moderno para o Funchal. A devastação provocada deu lugar a medidas de salubridade e de melhoramento da imagem da cidade turística. As três ribeiras 


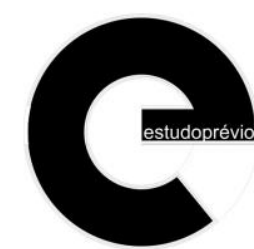

PT | P01 | EP14 | w2018

que atravessam a cidade foram encanadas, seus leitos corrigidos e alargadas ou abertas vias marginais as mesmas (Perdigão, 2015).

Encarregado dos trabalhos de limpeza e reconstrução, o Brigadeiro Reynaldo Oudinot propôs, no Plano para a Nova Cidade nas Angústias datado de 1804, um bairro habitacional burguês de traçado ortogonal e centrado por uma ampla praça, no território contíguo à cidade pré-existente. Esta proposta preconizou as intenções de expansão urbana planeada e organizada, segundo modelos ortogonais, de zonamento e de segregação social que despoletavam na Europa. $O$ traçado não se concretizou, mas a abertura de uma importante via e a construção de um fontenário permitiram a instalação de moradias isoladas naquela zona privilegiada (Perdigão, 2015).



PLANTA DA CIDADE DO FUNCHAL, CUDINOT, 1804, (FONTE CME, POLICOPIADO)

Figura 6 - "Planta da cidade do Funchal, Oudinot, 1804. Fonte CMF". 100 Anos do Plano Ventura Terra, Funchal a Cidade do Automóvel. OASRS - Delegação da Madeira. Funchal. 2015.

No final do século XIX, no Funchal, prevaleciam caraterísticas de burgo medieval, determinadas pela espontaneidade do seu desenvolvimento urbanístico e pelas diretrizes lançadas à época do seu povoamento. A cidade encontrava-se num estado primitivo. Destes fatores dá conta o projeto sobre a organização do serviço de limpeza da cidade, do vereador, José Joaquim de Freitas, caraterizando-se o Funchal com ruas estreitas, tortuosas e de péssima pavimentação, sem águas potáveis, sem esgotos, com imensos e infetos estábulos, com apenas um cemitério, uma "ignóbil" cadeia e um hospital no centro da cidade, próximo de ruídos e da agitação citadina. Estas circunstâncias eram prejudiciais à imagem de uma urbe, na qual o turismo, especialmente 0 terapêutico, constituía já uma importante fonte de receitas para a economia regional (adaptado de Vasconcelos, 2008). 
Na transição para o século XX, o Funchal pretendeu acompanhar a modernização urbana que se fazia sentir nas principais cidades europeias. A muralha já não se impunha na malha oitocentista e havia dado lugar à reformulação viária, ao verde, aos embelezamentos urbanos e aos primeiros equipamentos e infraestruturas consideradas modernas (adaptado de Matos, 2015a).

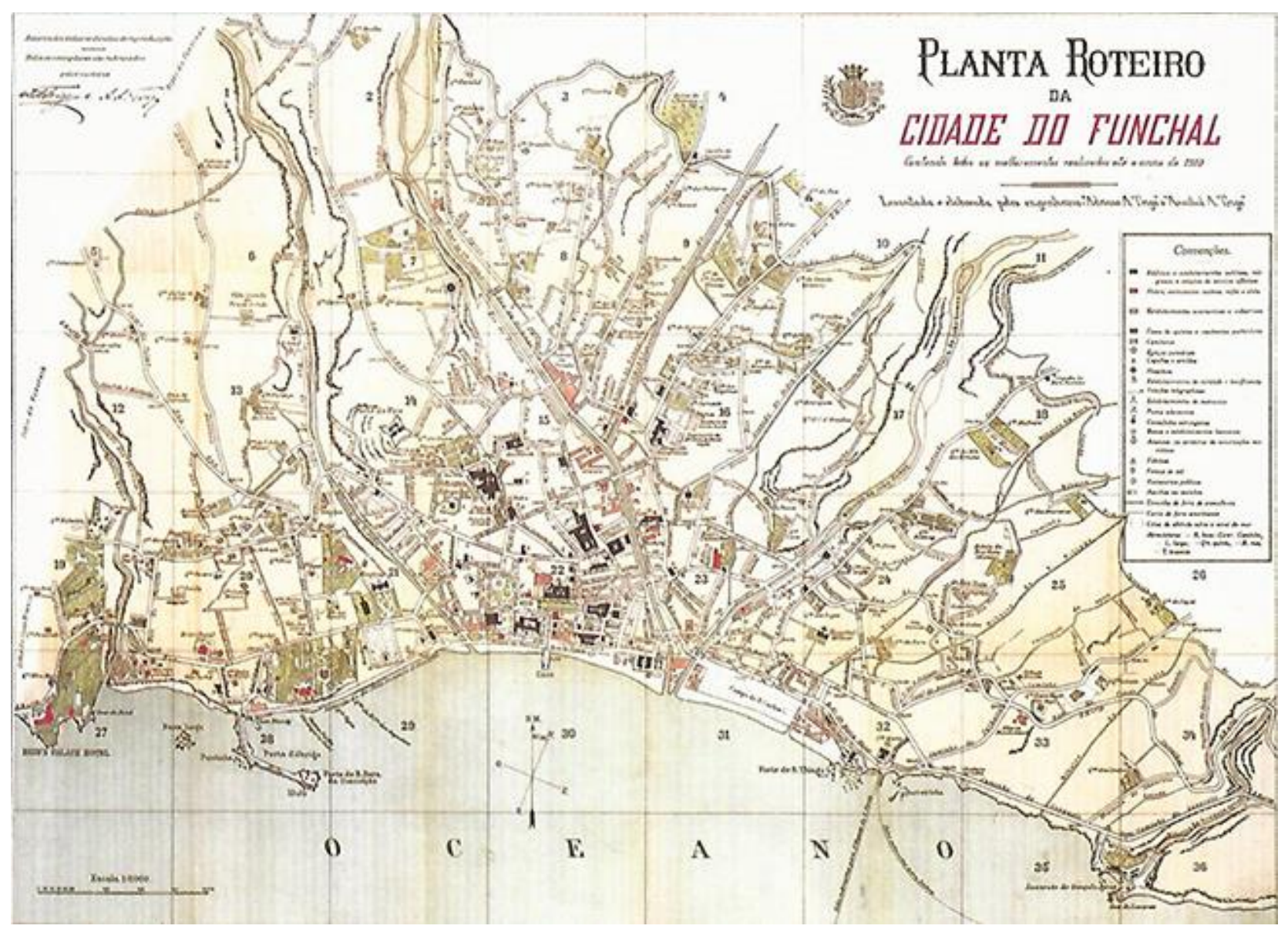

Figura 7 - "Planta Roteiro Cidade do Funchal. Trigo 1910. CMF e Planta Geral. Adriano Trigo. 1905. CMF". 100 Anos do Plano Ventura Terra, Funchal a Cidade do Automóvel. OASRS - Delegação da Madeira. Funchal. 2015.

Com a implantação da República, os novos poderes locais pretendiam um projeto de urbanização que reformulasse a cidade do Funchal dotando-a com modernos equipamentos urbanos e novas infraestruturas para o desenvolvimento da recente base económica, o turismo internacional. Ventura Terra respondeu ao desafio (Vasconcelos, 2015). Pela primeira vez, a cidade foi abordada como um todo e as medidas curativas e modernizadoras propostas resultaram radicais: vastos "boulevards" com duas faixas de rodagem e placa central arborizada, reservada a peões, rasgariam o tecido intrincado da urbe resolvendo os problemas viários. A praia era substituída por uma "bela avenida marginal, com 50 metros de largo por 1255 metros de comprimento" (Terra, 1915 - citado por Matos, 2008); a ribeira de João Gomes, depois de encanada, dava lugar também a uma avenida; o quarteirão do antigo Hospital Civil - um dos mais belos edifícios setecentistas da capital - era demolido; a Rua da Carreira alargada; a Sé e o Palácio de São Lourenço amputados e, a nascente e poente do centro, em nome da "salubridade, recreio da população, conforto e receção 


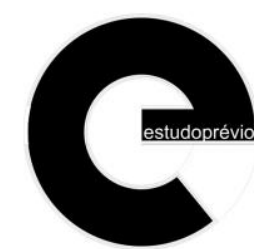

PT | P01 | EP14 | w2018

de turistas" (Terra, 1915 - citado por Matos, 2008), surgiam dois parques urbanos, um com generosa dimensões (Matos, 2015a).

Elas foram, todavia, tomadas em nome do bem comum e do progresso, enquadrando-se no espírito dos chamados "planos de melhoramentos". O modelo era a Paris de Haussman, já presente na "Memoire sur les études d'amèliorations et emblissements de Lisbonne" que o engenheiro Pézerat publicou em 1865. Foi nesta esteira que seguiu o autor do Plano de Melhoramentos do Funchal, quando lhe procurou dar eficácia e o brilho da cidade luz (adaptado de Matos, 2015a).

O plano de Ventura Terra foi importante no planeamento urbanístico da cidade do Funchal da primeira metade do século XX. Desenvolve uma proposta de modernização para a cidade, o primeiro desta magnitude no arquipélago, onde se aplicam os conceitos correntes do urbanismo francês da época visíveis nas grandes vias retilíneas, na utilização de rotundas para distribuição viária, amplas praças e parques na periferia. Porém, a visão, provavelmente demasiado grandiosa para a época não teve concretização (adaptado de Vasconcelos, 2008).

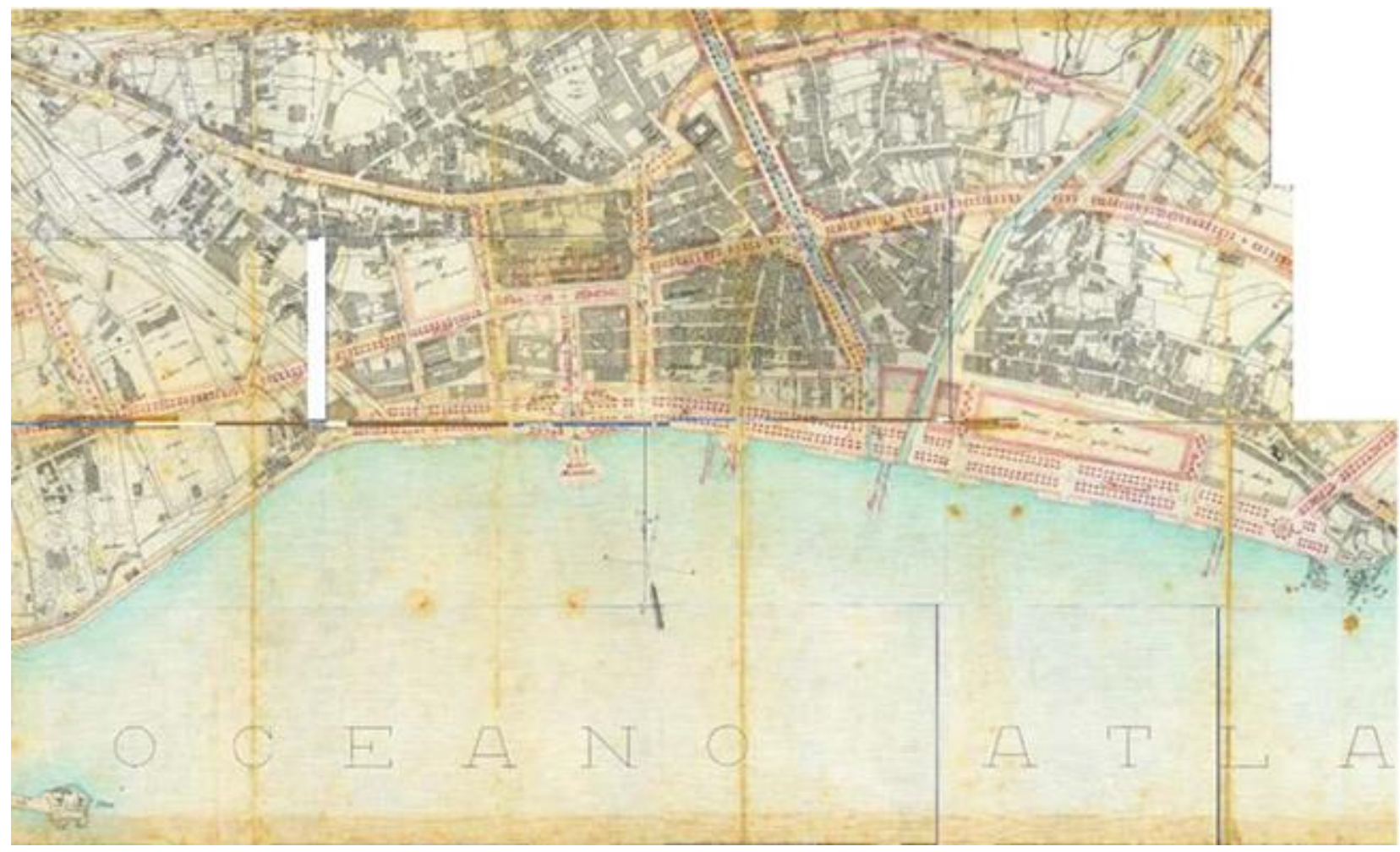

Figura 8 - "Projeto de Melhoramentos do Funchal. Planta. Fonte CMF". 100 Anos do Plano Ventura Terra, Funchal a Cidade do Automóvel. OASRS - Delegação da Madeira. Funchal. 2015.

Entre 1931 e 1933 o arquiteto Carlos Ramos foi responsável pela elaboração do Plano de Urbanização do Funchal, numa época em que eram estes planos a ditar bases para o planeamento das transformações territoriais no meio urbano. Embora este mais contido no entendimento da cidade enquanto estância turística, Ramos centrou preocupações na redefinição do núcleo urbano e propôs a sua modernização assente no desenho da rede viária, equipamentos e habitação, seguindo, os princípios do plano anterior. Também este plano não teve concretização (Perdigão, 2017). 
Em 1935 o Plano de Ventura Terra foi retomado, por iniciativa de Fernão de Ornelas na presidência da Câmara Municipal do Funchal. Apesar do plano não ter sido concretizado tal como traçado, a realização de obras para prosseguir os desejos de modernidade no Funchal, seguindo aquela base de planeamento urbanístico foi importante, determinando aquela que é hoje a cidade (adaptado de Perdigão, 2017). As avenidas Arriaga (antigo Passeio Público) e Zarco foram alargadas e ampliada a sua extensão, procedendo a ligações essenciais à fluidez do trânsito urbano. O prolongamento da Avenida Zarco ficou a cargo do arquiteto paisagista Caldeira Cabral, assim como a ligação à zona leste da cidade através da Rua do Bom Jesus e da Praça do Município criada junto ao edifício da Câmara, pelo arquiteto urbanista Faria da Costa, com o chafariz da autoria do arquiteto Raul Lino. O traçado da Avenida Oeste foi finalmente concretizado, renomeada Avenida do Infante, que consolidando o eixo de expansão da cidade para oeste, tendência que determinou a implantação hoteleira da fase seguinte (Perdigão, 2017).

Em 1941 e 1942 Caldeira Cabral ficou encarregue da execução do traçado para a Avenida Marginal, ou do Mar, sobre a Rua da Praia e até ao arsenal de São Tiago, da construção do Parque da Cidade (hoje de Santa Catarina), como contrapartida verde à reconfiguração da Avenida Arriaga, e dos melhoramentos no Jardim Municipal (1942). Ao mesmo tempo foram instalados equipamentos, lançadas as redes de saneamento básico e de eletricidade nas freguesias suburbanas e feita uma aposta na promoção da saúde pública (Perdigão, 2017).

As obras públicas e melhoramentos urbanos estavam em sintonia com as políticas do Estado Novo, visando o estímulo económico e emprego da população, mas muito em prol da construção da imagem turística do Funchal moderno (Perdigão, 2017). 


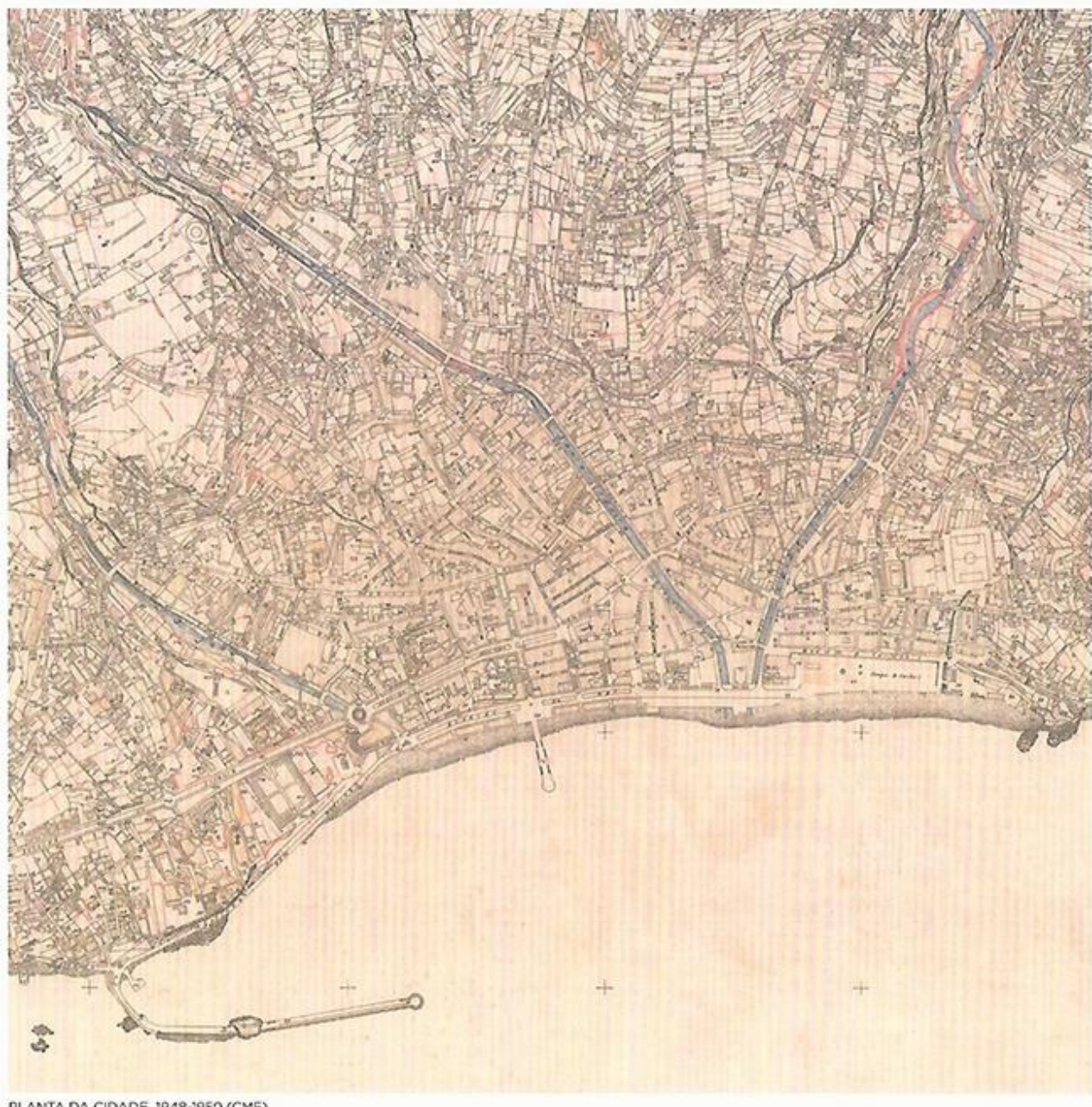

Figura 9 - "Planta da Cidade, 1948 - 1950. Fonte CMF". 100 Anos do Plano Ventura Terra, Funchal a Cidade do Automóvel. OASRS - Delegação da Madeira. Funchal. 2015.

\section{O Primeiro Plano Diretor do Funchal, o Plano de Rafael Botelho:}

O Funchal foi uma das primeiras cidades portuguesas a beneficiar de um Plano Diretor. Coordenado pelo arquiteto Rafael Botelho, a sua elaboração foi precedida por um debate aberto à comunidade, que ocorreu em 1969 com a realização dos Colóquios de Urbanismo. Daí resultou uma publicação com o mesmo nome, testemunho do caráter percursor e democrático do plano. Temas como a salvaguarda da cidade histórica (fundamentada no precioso levantamento de António Aragão), a conservação das quintas madeirenses e a preservação da originalíssima paisagem do anfiteatro da cidade eram as preocupações principais que o plano visava salvaguardar, tornando-se no primeiro instrumento de planeamento da llha a olhar a cidade no seu todo e a assumir a proteção do interesse público, na qualificação do espaço urbano e consequentemente, no bem-estar de toda a comunidade (adaptado de Matos, 2015b). 

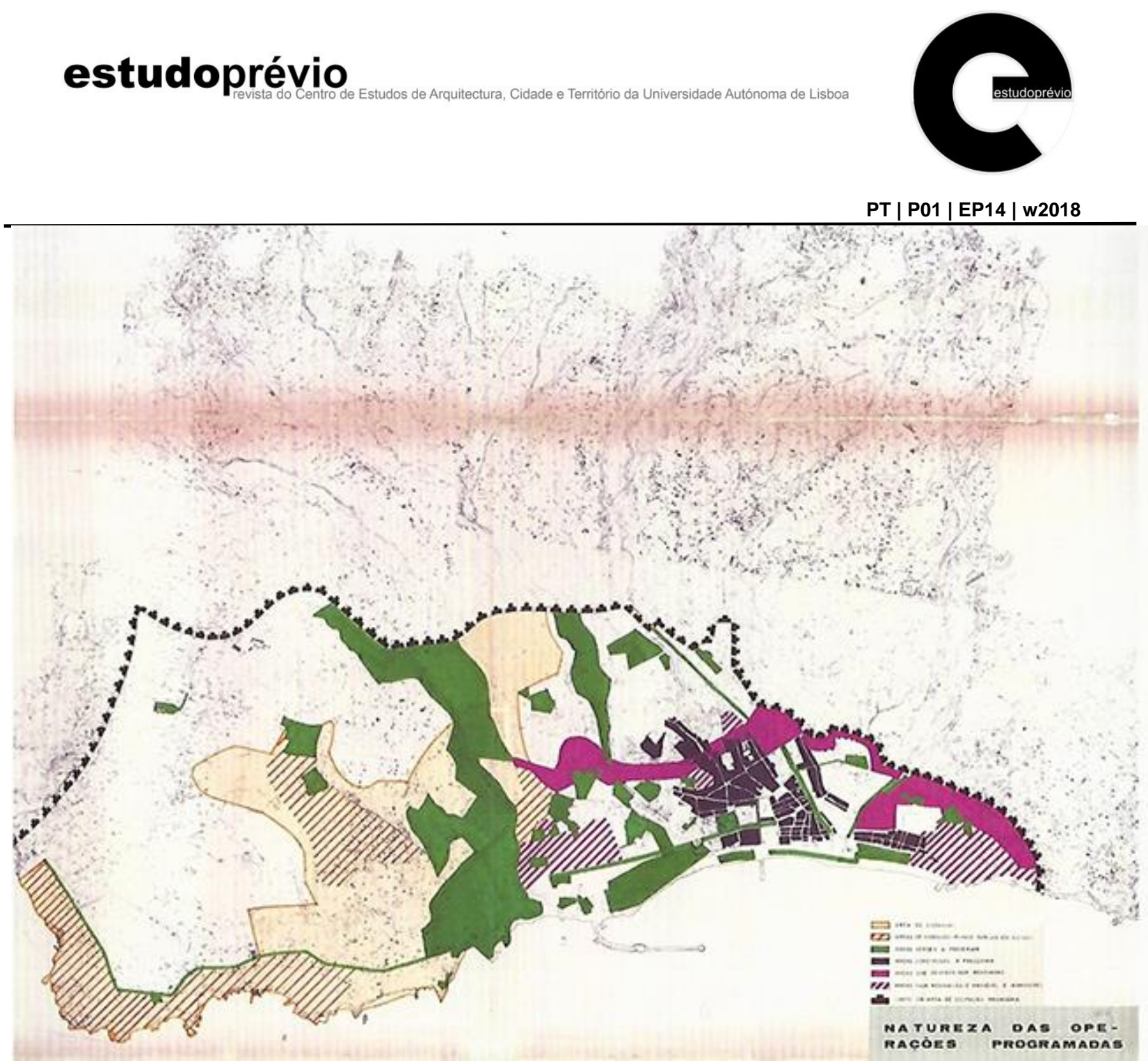

Figura 10 - "Plano Diretor de 1972 - Natureza das Operações programadas. Rafael Botelho. Planta. Fonte CMF”. Plano Rafael Botelho, Funchal 1969/72. OASRS - Delegação da Madeira. Funchal. 2015.

\section{A Autonomia Política e o Novo Modelo de Desenvolvimento Territorial da Região:}

A partir de 1950, o desenvolvimento do transporte automóvel e o crescimento do número de veículos na llha, impôs a construção de novas vias de comunicação. No entanto, a Guerra Colonial, nas décadas de 1960 / 1970 e a instabilidade política e a crise financeira vividas após a Revolução de 25 de Abril de 1974, refletiram-se nas poucas vias rodoviárias concretizadas. Em 1975, a rede viária tinha 265 quilómetros de extensão (Simões, 1983 - citado por Dantas, 2012), mantendo-se sem grandes alterações até finais da década de 1990 (Dantas, 2012).

Em 1970, a maior parte da população continuava a viver da agricultura. O espaço urbano limitavase a pequenos núcleos urbanos, como os das Vilas sedes de municípios da região e à cidade do Funchal, numa área que se estendia de Santa Maria Maior à Ponte do Ribeiro Seco. As estradas que ligavam os diferentes pontos da Madeira eram estreitas, porque a orografia não permitia grandes alargamentos, a luz elétrica e a água canalizada faltavam em muitas casas, devido, principalmente, à dispersão do povoamento. No mundo rural a mobilidade da população era muito reduzida (Dantas, 2012). 
A adesão de Portugal à C.E.E. (1986), trouxe alento à economia do País e permitiu, através das ajudas comunitárias, o investimento em infraestruturas. A Região Autónoma da Madeira (RAM) apostou na construção da rede de estradas e das redes de infraestruturas básicas, nomeadamente nas redes de água canalizada, elétrica e de saneamento básico, praticamente inexistentes nas Ilhas (Dantas, 2012).

O desenvolvimento dos meios de comunicação e de transporte, levou a uma nova dinâmica do centro e da periferia das cidades, encurtando distâncias entre os núcleos urbanos, diversificando as atividades económicas, incrementando o investimento privado nomeadamente no imobiliário e no aparecimento de mais unidades hoteleiras, conduzindo a profundas transformações na organização e a expansão do espaço urbano, sobretudo com a banalização do uso do automóvel particular. Este invade áreas muito afastadas, possibilita o crescimento do tipo suburbano e periurbano, não estruturado, em função do traçado das vias que vão sendo criadas, dispersa as residências levando-as para lugares cada vez mais distantes e contribui para o aparecimento de novas centralidades (adaptado de Dantas, 2012).

No arquipélago da Madeira, durante mais de quatrocentos anos só existiu uma cidade - Funchal. A situação alterou-se a partir da década de 1990, com a criação de mais cinco cidades, quatro das quais na encosta sul da Madeira: Câmara de Lobos, Caniço, Santa Cruz e Machico, enquanto na encosta norte Santana aparece isolada (Dantas, 2012).

No contexto regional e à exceção do Funchal, durante muitos anos, o processo de urbanização se desenrolou num contexto de ausência de políticas de ordenamento do território (Dantas, 2012). Só

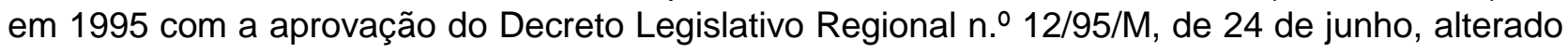
pelo Decreto Legislativo Regional n. 9 9/97/M, de 18 de julho é aprovado o primeiro (e até agora único) Plano de Ordenamento do Território da Região Autónoma da Madeira (POTRAM). Este documento legislativo "estabelece as orientações gerais de planeamento e desenvolvimento das intervenções respeitantes ao uso e ocupação do solo, defesa e proteção do ambiente e do património histórico, distribuição da população no território e estrutura da rede urbana" (Fernandes, 2011). Porém na prática o POTRAM tornou-se um instrumento de gestão territorial muitas vezes ignorado e secundarizado e cuja importância hoje ainda não é compreendida, num tempo em que aceleradamente se verificaram profundas alterações no território e na sua ocupação, pouco influenciadas e muitas vezes contra as orientações estabelecidas por este, sendo exemplo disto a ocupação do litoral e a expansão urbana que se tem vindo a verificar para cotas cada vez mais altas, colocando em causa o equilíbrio biofísico, ambiental e a segurança dos núcleos mais urbanos, as vilas e as cidades, que ficam mais vulneráveis aos fenómenos atmosféricos / climáticos, bem como a qualidade de vida de quem ocupa estas zonas altas, com a falta da devida infraestruturação básica e do espaço público envolvente. 


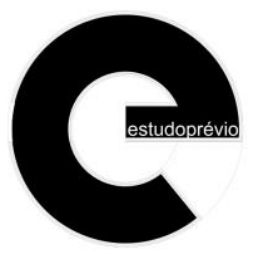

PT | P01 | EP14 | w2018

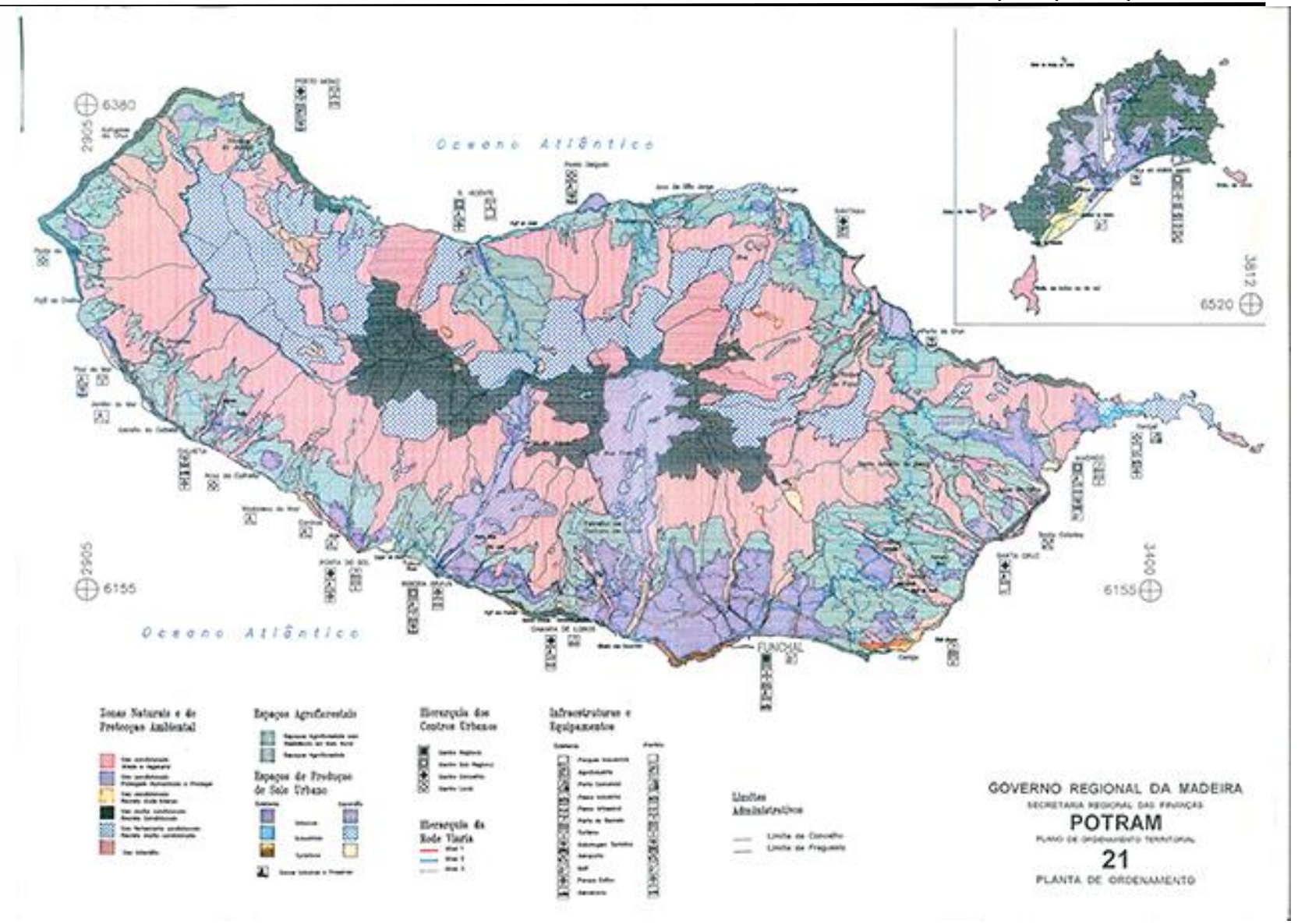

Figura 11 - "POTRAM. Planta de Ordenamento". Fonte Governo Regional da Madeira. Funchal. 1997.

Também em 1997, o Município do Funchal aprova o seu Plano Diretor Municipal (PDM). Este tinha como principais objetivos, contribuir para a reconversão da base económica em torno de atividades tradicionais e alternativas com maior índice de criação de valor acrescentado, contribuir para o aproveitamento de vantagens competitivas associadas à existência de polos de excelência dos sistemas de educação/formação e de ciência e tecnologia, racionalizar e programar o crescimento urbano e requalificar a estrutura funcional, preservar e valorizar todos os recursos naturais do Concelho, salvaguardar e ordenar a estrutura verde, satisfazer as necessidades do Concelho a nível das acessibilidades e dos sistemas de transportes, melhorar os níveis de cobertura por parte das principais infraestruturas urbanas, preservar, recuperar e proteger o património cultural, desenvolver e pormenorizar regras e diretivas estabelecidas em planos de nível superior, fornecer indicadores para o planeamento, designadamente para a elaboração de outros planos municipais ou planos de carácter sub-regional ou regional, servir de enquadramento à elaboração de planos de atividade do município e permitir ao município a criação de uma estrutura de gestão urbanística por unidades de território, com existência e gestão autónomas (PDM Funchal, 2008).

Este plano foi elaborado no mesmo período temporal do POTRAM, embora pouco influenciado pelo mesmo. A pouca prática de planeamento e o pouco interesse político nestes instrumentos, tornaram relativa a complementaridade e a sintonia que seria necessária entre estes. 
O PDM permitiu pensar o Município num todo, tentando disciplinar o crescimento urbanístico crescente fora dos núcleos mais antigos, introduziu a dimensão mínima da parcela a edificar (400m2), os índices urbanísticos com o intuito de controlar a impermeabilização do solo e a volumetria das construções. Introduz também afastamentos e alinhamentos que disciplinaram as frentes de rua, parâmetros urbanísticos que no seu conjunto se ajustaram no geral à realidade local. Infelizmente e quando já era evidente a expansão da cidade para as zonas mais altas, com a consequente proliferação de construções de génese ilegal o plano não conseguiu responder e travar a expansão desmesurada para a montanha, o concelho que a ser também por via disto, mais vulnerável a situações de risco, nomeadamente de cheias, de inundação das suas principais ribeiras e de incêndios florestais, atendendo a proximidade da mancha urbana a estas áreas e onde as carências ao nível das acessibilidades e de espaço público de qualidade se tornou evidente. Tal como o POTRAM, este instrumento de gestão territorial, não foi orientador do desenvolvimento equilibrado do território municipal, que sofreu com a forte pressão imobiliária que ocasionou a perda de importante património edificado e não conseguiu proteger a orla marítima da ocupação hoteleira desenfreada que condicionou fortemente o acesso ao mar por parte dos cidadãos.

O PDM orientou a expansão da cidade para oeste, nomeadamente para a Ajuda e Amparo, onde surgiu uma nova centralidade.

Durante a vigência deste Plano Diretor (20 anos), foram também elaborados os Planos de Urbanização (PU) do Amparo, do Palheiro, do Infante, da Levada do Cavalo, da Ribeira de Santa Luzia e da Ribeira de João Gomes. No tocante a Planos de Pormenor (PP) foram elaborados os do Castanheiro, da Praia Formosa, do Projeto Urbano AR1/CE de Santa Luzia, da Quinta do Poço e da Vila Giorgi.

Muitos destes instrumentos alteraram significativamente o PDM, alguns de forma positiva, (caso do PU do Amparo), redefinindo o desenho urbano proposto, os índices de edificabilidade; outros foram muito negativos, como é o caso do PP do Infante, que permitiu a construção de edificado de volumetria excessiva para fins turísticos, desenquadrados com a envolvente e com forte impacto na paisagem. 


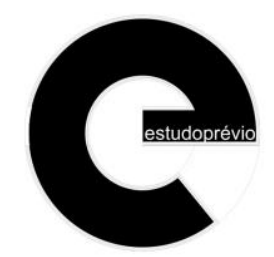

PT | P01 | EP14 | w2018

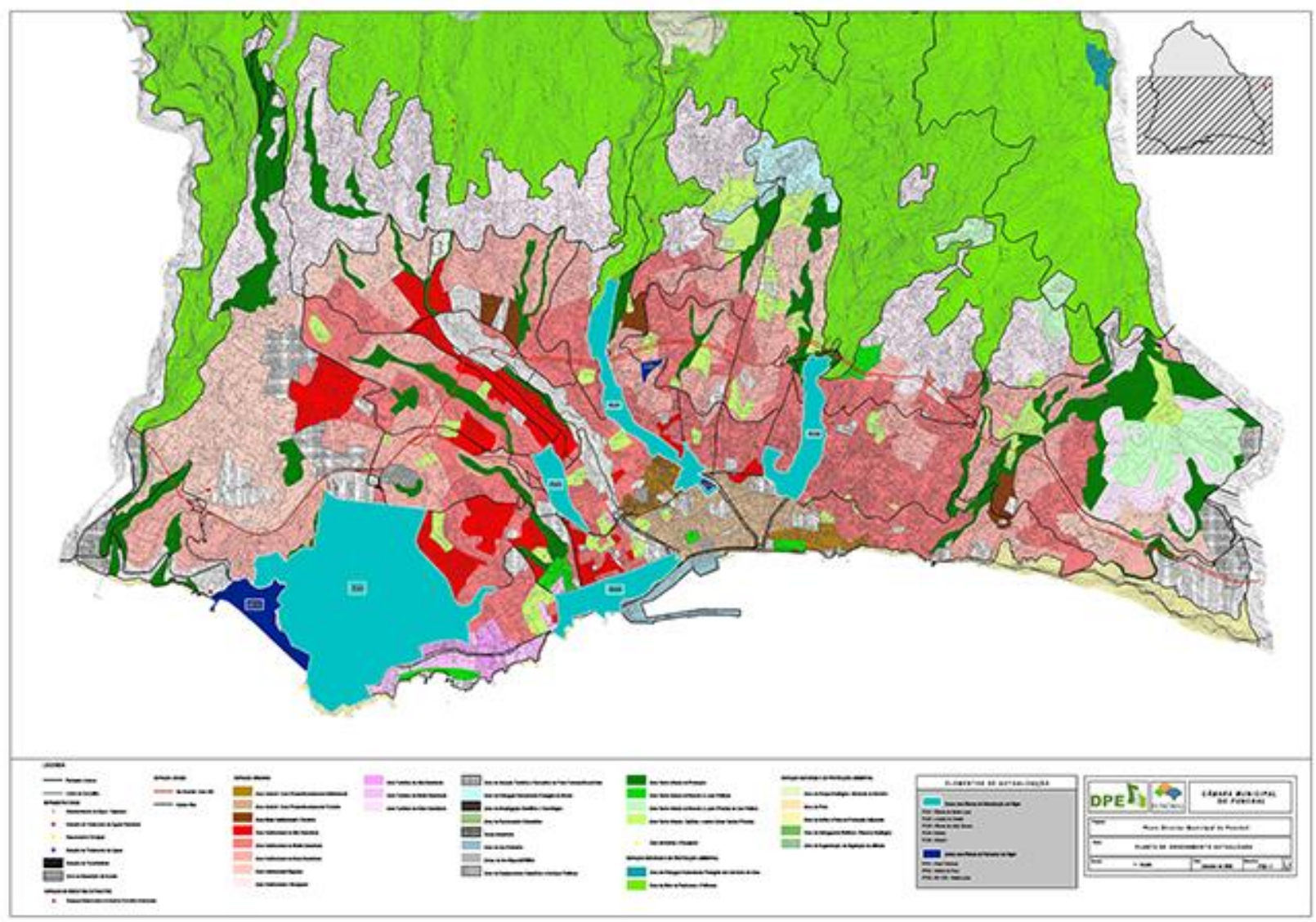

Figura 12 - "PDM Funchal. Planta Parcial de Ordenamento". DPE - CMF. 2008.

Na primeira década do século XXI, surge a primeira geração de Planos Diretores Municipais nos restantes nove concelhos, considerados como instrumentos básicos de ordenamento do território e que visam contribuir para um modelo coerente de desenvolvimento dos diversos municípios mediante a definição de orientações gerais do planeamento e da gestão urbanística. Em muitos destes Municípios são escassos os Planos de Urbanização ou de Pormenor.

O aparecimento tardio destes instrumentos teve consequências nomeadamente nos concelhos vizinhos ao Funchal (Santa Cruz e Câmara de Lobos), onde a ausência de planeamento e de regras de regulação da atividade construtiva, aliadas a uma forte pressão imobiliária, criaram problemas com repercussões múltiplas nomeadamente de impermeabilização excessiva do solo, falta de dimensionamento adequado de infraestruturas, estacionamentos e de vias de acesso, descaracterização da paisagem, falta de espaços e de equipamentos de utilização pública.

Importa também referir que os PDM na RAM, aparecem para permitir o acesso a fundos comunitários, o que até aqui não acontecia, mesmo existindo orientação nacional prevista na sequência da publicação do Decreto Lei n.ำ69/90, de 2 de março.

Em meados da década em curso tem inicio o segundo ciclo de elaboração de Planos Diretores Municipais. As revisões destes instrumentos surgem por se considerar que estes se encontram desatualizados face às atuais dinâmicas territoriais. Este processo foi já concluído pelos municípios de Ponta do Sol, Ribeira Brava, Calheta, Santana e Funchal, estando também já em discussão 
pública o PDM de Câmara de Lobos. Todos estes instrumentos de gestão territorial têm em comum uma nova forma de olhar o território com preocupações ao nível da expansão urbana, onde se pretende travar a mesma para lá dos limites atuais, nomeadamente para as cotas mais altas; condicionar a ocupação de áreas de risco, definindo também unidades de intervenção especial que permitam a concretização de objetivos operacionais que visem a promoção e incentivo à qualificação do solo, a requalificação e ordenamento da rede viária, a reabilitação urbana, a mobilidade urbana e a criação de mais e melhor espaço público. É também evidente a preocupação transversal em redefinir áreas afetas as atividades económicas.

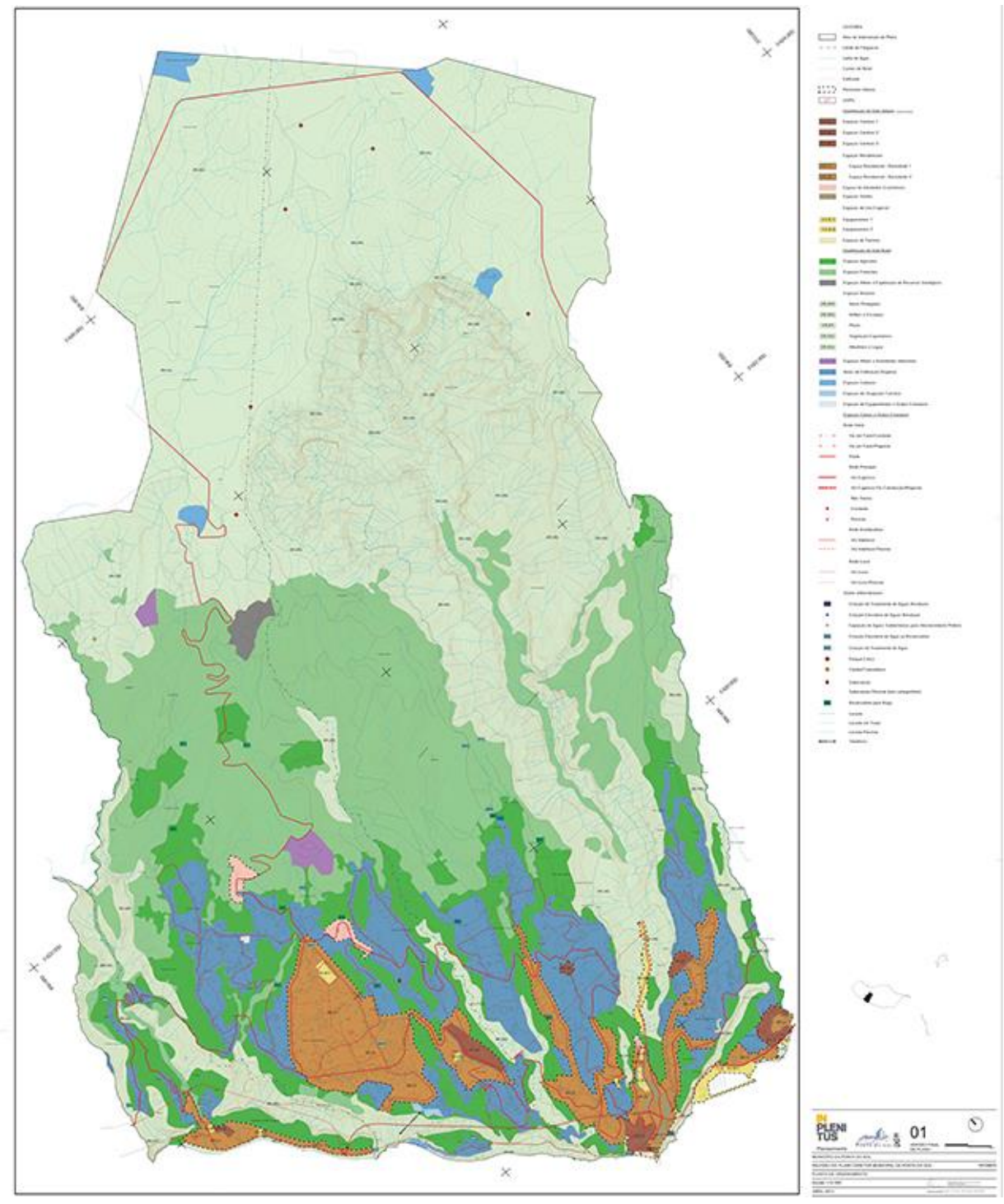

Figura 13 - "PDM Ponta do Sol. Planta de Ordenamento". Fonte CMPS. 2013.

Em 2017, também foram introduzidas, pelo Decreto Legislativo Regional $n .$. 18/2017/M, de 27 de junho, alterações ao sistema regional de gestão territorial na RAM (até aqui regulado pelo Decreto Legislativo Regional n. ${ }^{4}$ 43/2008/M, de 23 de dezembro), adaptando à região a Lei $n . \circ 31 / 2014$, de 30 de maio, que veio estabelecer as atuais bases gerais da política pública de solos, de ordenamento do território e de urbanismo e no cumprimento também do estatuído no seu artigo 
81.., o Decreto Lei n. $.080 / 2015$, de 14 de maio, que desenvolveu essas bases e definiu o regime de coordenação dos âmbitos nacional, regional, intermunicipal e municipal do sistema de gestão territorial, o regime geral de uso do solo e o regime de elaboração, aprovação, execução e avaliação dos instrumentos de gestão territorial.

\section{O que falta fazer - Uma análise crítica:}

Embora a região se encontre em pleno processo de revisão dos instrumentos de planeamento municipal, é urgente a revisão do seu principal instrumento de natureza estratégica que nos termos do seu sistema regional de gestão territorial se passará a designar de Programa Regional de Ordenamento do Território da Região Autónoma da Madeira (PROTRAM). Este instrumento permitirá ter uma visão atual do território e definir uma estratégia de desenvolvimento integrado (e não desconexo como agora), permitindo também compatibilizar políticas e lacunas que hoje não promovem uma gestão integrada e eficaz do território regional.

A Ilha da Madeira concentra $98 \%$ da população regional. As vulnerabilidades socioeconómicas e os riscos de natureza ambiental são problemas que urge identificar, estudar e mitigar, integrados nos instrumentos de natureza territorial e regulamentar a rever ou a elaborar, tendo em conta os recorrentes efeitos cada vez mais importantes resultantes das alterações climáticas, das mudanças que se impõem do paradigma de desenvolvimento económico e social, anteriormente assente na infraestruturação e na resposta as necessidades básicas da população. Como também na sustentabilidade e coesão socio-territorial que importa encontrar para o futuro destas Ilhas (adaptado de Barroco, 2012).

A par disto importa que a região aposte na implementação de outros instrumentos de gestão territorial, nomeadamente os Programas Especiais de Ordenamento, tendo à cabeça os Programas de Ordenamento da Orla Costeira (POOC), ainda não implementados na RAM, situação única no território nacional. A par, importa também definir as Reserva Ecológica e a Reserva Agrícola Regionais, que hoje não passam de meros limites do Parque Natural já desatualizados e das áreas com maior aptidão agrícola que não estão sujeitas a nenhum tipo de procedimento de desafetação, o que desvirtua a razão de ser destes regimes territoriais especiais, permitindo de forma responsável abrir caminho para a elaboração realista e adequada do PROTRAM.

Tudo indica que há neste momento intenção de trilhar um caminho novo no tocante a estes instrumentos, está anunciado o lançamento do concurso para a elaboração do POOC da Madeira até ao final de 2018 (o processo de elaboração do POOC do Porto Santo já foi iniciado), tal como do novo PROTRAM, o que renova a esperança numa gestão do território mais eficiente.

\section{Bibliografia:}

ACAPORAMA - Caraterização do Território. Grupo de Ação Local ACAPORAMA. Funchal. 2016. Consultado em: 13/07/2018. Site: http://www.acaporama.org/proderam2020/index.php/a-estrategia/caracterizacao-doterritorio

ARAGÃO, António - O Espírito do Lugar, A Cidade do Funchal. A. Aragão. 1a Edição. Rio de Mouro. 1992. BARROCO, Ana; AFONSO, Rute - Planeamento Territorial nos Territórios Insulares Portugueses. Malha Urbana. № 12. Lisboa. 2012. 
CARITA, Rui - Arquitetura Militar na Madeira, Séculos XVI a XIX. Fundação Calouste Gulbenkian. Lisboa. 1982.

CARITA, Rui - História do Funchal. Associação Académica da Universidade da Madeira. Grafimares, Lda. $2^{\text {a }}$ Edição. Funchal. 2017.

DANTAS, Maria Gilda de Andrade Fernandes - A Rede Urbana e Desenvolvimento na Região Autónoma da Madeira. Dissertação de Doutoramento em Geografia e Planeamento Territorial, Especialidade em Planeamento e Ordenamento do Território. FCSH-UNL. Lisboa. 2012.

DECRETO LEGISLATIVO REGIONAL n.ำ 18/2017/M, 27 de junho. JORAM. 2ª Série. 2017.

FERNANDES, Fabiana Laura Candelária. Ordenamento do Território em Pequenas llhas: Caso de Estudo da Madeira. Dissertação de Mestrado em Engenharia do Ambiente. Universidade de Aveiro. Aveiro. 2011.

MATOS, Rui Campos - Nos 100 Anos do Plano Ventura Terra. 100 Anos do Plano Ventura Terra, Funchal a Cidade do Automóvel. OASRS - Delegação da Madeira. Funchal. 2015. (a)

MATOS, Rui Campos - Uma Ideia de Cidade. Plano Rafael Botelho, Funchal 1969/72. OASRS - Delegação da Madeira. Funchal. 2015. (b)

PERDIGÃO, Cristina - Alvores da Modernidade no Funchal Oitocentista. 100 Anos do Plano Ventura Terra, Funchal a Cidade do Automóvel. OASRS - Delegação da Madeira. Funchal. 2015.

PERDIGÃO, Cristina Sófia Andrade - O Turismo na Madeira, Dinâmicas e Ordenamento do Turismo em Territórios Insulares. Dissertação de Doutoramento em Urbanismo. FA-UL. Lisboa. 2017.

POTRAM - Regulamento. Governo Regional da Madeira. Funchal. 1997.

PDM FUNCHAL - Regulamento. Câmara Municipal do Funchal. Funchal. 2008.

VASCONCELOS, Teresa - O Plano Ventura Terra e a Modernização do Funchal (Primeira Metade do Século XX). Coleção Funchal 500 Anos. Empresa Municipal Funchal 500 Anos. Funchal. 2008.

VASCONCELOS, Teresa - Ventura Terra no Funchal: Um Plano Centenário. 100 Anos do Plano Ventura Terra, Funchal a Cidade do Automóvel. OASRS - Delegação da Madeira. Funchal. 2015.

\section{Biografia:}

José Roberto Ribeiro Rodrigues - arquiteto.

Com mestrado integrado em Arquitetura no ano de 2015 pela Universidade Autónoma de Lisboa (DA - UAL).

Mestrando do Mestrado em Ordenamento do Território \& Sistemas de Informação Geográfica na FCSH UNL.

É Funcionário do Gabinete Técnico da Câmara Municipal de Ponta do Sol, com atividade suspensa por estar a cumprir funções parlamentares na Assembleia Legislativa da Madeira desde 2011, onde também preside a 3므 Comissão Especializada de Ambiente e Recursos Naturais, desde 2017.

Fixou também atelier próprio em 2016, atelier "RR Arquitecto - Arquitectura + Planeamento Urbano", com atividade continua e trabalhos desenvolvidos no mercado regional.

e-mail: rrodrigues.arquitecto@gmail.com.

\footnotetext{
' Aluvião: Inundação provocada por grande volume de água; cheia; enxurrada. Dicionário da língua Portuguesa Priberam: https://dicionario.priberam.org.
} 